\title{
Phasing of muscle gene expression with fasting-induced recovery growth in Atlantic salmon Neil I Bower ${ }^{1}$, Richard G Taylor ${ }^{2}$ and Ian A Johnston*1
}

\author{
Address: ${ }^{1}$ Gatty Marine Laboratory, School of Biology, University of St Andrews, St Andrews, Fife, KY16 8LB, UK and ${ }^{2}$ EWOS Innovation, 4335 \\ Dirdal, Norway \\ Email: Neil I Bower - nib@st-andrews.ac.uk; Richard G Taylor - Richard.Taylor@ewos.com; Ian A Johnston* - iaj@st-andrews.ac.uk \\ * Corresponding author
}

Published: 24 August 2009

Frontiers in Zoology 2009, 6:18 doi:10.1186/1742-9994-6-18
Received: 7 May 2009

Accepted: 24 August 2009

This article is available from: http://www.frontiersinzoology.com/content/6/1//8

(c) 2009 Bower et al; licensee BioMed Central Ltd.

This is an Open Access article distributed under the terms of the Creative Commons Attribution License (http://creativecommons.org/licenses/by/2.0), which permits unrestricted use, distribution, and reproduction in any medium, provided the original work is properly cited.

\begin{abstract}
Background: Many fish species experience long periods of fasting in nature often associated with seasonal reductions in water temperature and prey availability or spawning migrations. During periods of nutrient restriction, changes in metabolism occur to provide cellular energy via catabolic processes. Muscle is particularly affected by prolonged fasting as myofibrillar proteins act as a major energy source. To investigate the mechanisms of metabolic reorganisation with fasting and refeeding in a saltwater stage of Atlantic salmon (Salmo salar $L$.) we analysed the expression of genes involved in myogenesis, growth signalling, lipid biosynthesis and myofibrillar protein degradation and synthesis pathways using QPCR.

Results: Hierarchical clustering of gene expression data revealed three clusters. The first cluster comprised genes involved in lipid metabolism and triacylglycerol synthesis (ALDOB, DGATI and LPL) which had peak expression 3-14d after refeeding. The second cluster comprised ADIPOQ, MLC2, IGF-I and TALDOI, with peak expression I4-32d after refeeding. Cluster III contained genes strongly down regulated as an initial response to feeding and included the ubiquitin ligases MuRFI and MAFbx, myogenic regulatory factors and some metabolic genes.

Conclusion: Early responses to refeeding in fasted salmon included the synthesis of triacylglycerols and activation of the adipogenic differentiation program. Inhibition of MuRFI and MAFbx respectively may result in decreased degradation and concomitant increased production of myofibrillar proteins. Both of these processes preceded any increase in expression of myogenic regulatory factors and IGF-I. These responses could be a necessary strategy for an animal adapted to long periods of food deprivation whereby energy reserves are replenished prior to the resumption of myogenesis.
\end{abstract}

\section{Background}

Fasting is a natural phenomenon in high latitude fish and is associated with low winter temperatures, short-days which restrict feeding opportunities and/or reduced availability of prey items. Atlantic salmon (Salmo salar L.) experience periods of fasting during the completion of their lifecycle, when adult fish return to freshwater to spawn. Reproduction and migration in anadromous salmonids requires substantial energy input, which is often mobilised from stores in visceral and somatic tissues [1]. These energy stores are mostly acquired in the ocean [2], since salmon cease feeding prior to and during their upstream 
migration to spawning grounds in freshwater $[3,4]$. Considerable energy is also used for gonadal development, nest construction, courtship and intrasexual competition $[1,5-8]$. Kelts (previously spawned adult salmon), which overwinter in fresh water pools and descend in spring [9], rely entirely on stored energy reserves to survive and are often in an emaciated condition [10]. Juvenile salmon may also experience fasting, as juveniles which show delayed levels of activity, delay their migration to the sea and overwinter in freshwater [11]. To survive the winter months, these fish rely heavily on lipid reserves accumulated during autumn [12-14].

Fasting in fish is associated with a reduction in metabolic rate at the whole animal level [15]. Reductions in protein synthesis with extended fasting are undoubtedly an important component of the observed metabolic depression [16]. Net changes in tissue mass are a function of the balance between protein synthesis and degradation. In rainbow trout liver prolonged starvation resulted in no change in fractional protein synthesis rates, a large decrease in absolute protein synthesis rates and increased protein degradation rates [17]. The amino acids produced from the net mobilisation of proteins from the myotomal muscles represent a major energy source for other tissues $[18,19]$. Fish myotomes contain slow and fast muscle fibre types primarily used in sustained and burst swimming respectively $[20,21]$. Biochemical and ultrastructural studies have shown that slow muscle is relatively spared from the effects of fasting, presumably because it is needed for continuous swimming at all speeds $[22,23]$. Atrophy in fast muscle follows depletion of glycogen and lipid stores and is associated with a decrease in myofibrillar diameter, and a preferential degradation of peripheral myofilaments [23]. Feeding fish to appetite following fasting or a period of growth restriction results in faster growth relative to continuously fed control groups, a phenomenon referred to as compensatory or catch-up growth $[24,25]$. The primary mechanism underlying compensatory growth with food restriction in Atlantic salmon is an increase in feeding intensity [25].

Fasting-refeeding protocols have become one of the main manipulative tools used to investigate the molecular and genetic mechanisms regulating growth [26-29]. As in mammals, Insulin-like growth factor-I (IGF-I) and IGF-II are the key hormones which stimulate protein synthesis in fish muscle $[26,29,30]$. IGF-I from the liver is delivered to the muscle by the circulation and in addition both IGF-I and IGF-II are locally synthesized in response to environmental and nutritional stimuli [31]. The complete IGFsystem in fish comprises 4 splice variants, several membrane receptors and six IGF-binding proteins which act on the PI3K/AKT/mTOR pathway [31,29]. Rescan et al., [28] used a cDNA microarray containing 9023 rainbow trout
(Oncorhynchus mykiss) sequences to provide a general description of some of the changes in muscle gene expression that accompanied recovery growth following fasting. Fasting was associated with an upregulation of cysteine protease cathepsins and components of the ubiquitinproteosome involved in protein degradation as well as tuberous sclerosis component 2 (TSC2) an inhibitor of mTOR function and the translational repressor 4E-BP1 [28,32]. 4 to 11 days after refeeding there was a downregulation of genes involved in protein catabolism and an upregulation of genes involved in translation, protein folding and maturation and ribosome formation [28].

In mammals, the signals that regulate muscle atrophy and hypertrophy are linked through the PI3K/AKT/mTOR pathway [33]. Activation of the PI3K/AKT/mTOR pathway by IGF-I causes a phosphorylation cascade that leads to an increase in translation and therefore protein synthesis, resulting in skeletal muscle hypertrophy [34]. Phosphorylation of AKT also results in inhibition of key regulators of skeletal muscle atrophy, the muscle specific ubiquitin ligases MAFbx and MuRF1, through phosphorylation of the FOXO transcription factors [35]. Conversely, dephosphorylation of FOXO transcription factors, for example during nutrient restriction, results in increased expression of MuRF1 and MAFbx. MAFbx and MuRF1 are E3 ubiquitin ligases involved in the targeting of proteins, such as myosin light chain 2, for degradation via the ubiquitin pathway $[35,36]$. MAFbx targets elongation initiation factor 3-f (eif3-f) for degradation, a key regulator of mTOR mediated translation of muscle structural proteins including myosin heavy chain and desmin $[37,38]$. MuRF1 has also recently been shown to depress energy metabolism in mammalian muscle via effects on pyruvate dehydrogenase and creatine kinase [39]. Furthermore, MyoD, a master transcriptional factor for myogenesis is a target of MAFbx [40], indicating a widespread role of ubiquitin ligases in regulating muscle growth in mammals.

Quantitative PCR (qPCR), if performed with appropriate normalisation, statistical analysis and under standardised operating procedures such as those described in the Minimum Information for publication of Quantitative realtime Experiments guidelines (MIQE), is the method of choice for reliably quantifying changes in gene expression [41]. In the present study, qPCR was used to investigate the phasing of gene expression in the fast muscle of Atlantic salmon during fasting-induced recovery growth. Since the response of both MuRF1 and MAFbx expression to fasting-refeeding has not been investigated in Atlantic salmon we particularly wanted to determine the expression of MuRF1 and MAFbx in relation to IGF-I and marker genes for myogenesis, glucose homeostasis and lipid metabolism. 


\section{Methods}

The methods described in this paper for qPCR analysis of gene expression are compatible with the MIQE guidelines [41].

\section{Fish and experimental design}

All experiments were conducted at EWOS Innovation, Dirdal, Norway and were approved by the local animal welfare committee. Atlantic salmon (Salmo salar. L $1327 \mathrm{~g}$ $\pm 336.1 \mathrm{~g}$, Mean $\pm \mathrm{SD}, \mathrm{n}=55$ ) were individually passive induced transponder (PIT) tagged (Fish Eagle, Lechlade, Gloucestershire England) so that growth rate could be calculated. Fish were fasted for 32 days then fed to satiation with a commercial feed (EWOS Innovation, 52\% fish meal, $13 \%$ rape seed oil, $12 \%$ wheat protein, $10 \%$ fish oil, $5 \%$ pea protein, $5 \%$ soy protein, $3 \%$ krill meal, vitamin C$350.29 \%$, vitamin mix $0.15 \%$, vitamin E-50 $0.03 \%$, methionine $0.02 \%$ ) for 32 days. The average daily temperature was $7.8^{\circ} \mathrm{C}$, oxygen was $13.96 \mathrm{mg} \mathrm{L}^{-1}$, and average daily salinity was $28.9 \mathrm{ppm}$. Samples were taken at $0 \mathrm{~d}, 3$ $\mathrm{d}, 7 \mathrm{~d}, 14 \mathrm{~d}$ and $32 \mathrm{~d}$ following refeeding with 8 fish sampled at each time point. Fish were humanely killed by Schedule 1 of the Animals (Scientific Procedures) Act 1986 (Home Office Code of Practice. HMSO: London Jan. 1997) and individual mass and fork lengths measured. Fast muscle was dissected from the dorsal myotome between 0.6 and 0.7 standard length (tip of snout to last vertebrae). Tissues were snap frozen in liquid nitrogen and stored at $-80^{\circ} \mathrm{C}$ until analysed. Growth was measured as the Thermal Growth Co-efficient (TGC $=\left[\left(\mathrm{M}_{2}{ }^{0.333_{-}}\right.\right.$ $M^{0.333}$ )(degree days) ${ }^{-1 *} 1000$ ] where $M_{1}$ and $M_{2}$ were start and final body weights respectively. Degree days values are the sum of the ${ }^{\circ} \mathrm{C}$ values for each day of the experiment.

\section{RNA extraction and cDNA synthesis}

Total RNA was extracted by addition of $100 \mathrm{mg}$ of muscle to Lysing matrix D (Qbiogene, Irvine, California) with 1 $\mathrm{ml}$ Tri Reagent (Sigma, Gillingham, Dorset, UK) and homogenised using a Fast Prep instrument (Qbiogene, Irvine, California). Total RNA was quantified based on absorbance at $260 \mathrm{~nm}$. Only samples with a A260/280 ratio between 1.8 and 2.1, and a an A260/230 ratio above 1.8 were used for reverse transcription. Genomic DNA contamination was removed by treatment with Turbo DNA-free (Ambion, Austin, Texas, USA), and the integrity of purified RNA confirmed by agarose gel electrophoresis. First strand cDNA was synthesised from 1 ug total RNA using Superscript III (Invitrogen, Carlsbad, CA, USA) as per manufacturer's guidelines

\section{Primer design}

Previously published primers were used for LPL [42]. Primers were designed using Net primer (Premier BioSoft) to have $\mathrm{Tm}$ of $60^{\circ} \mathrm{C}$, and where possible, were designed to cross an exon-exon junction to avoid amplification of contaminating genomic DNA. The primers, amplicon size, amplicon melting temperature and accession numbers of genes used for QPCR are listed in table 1. The following genes were studied: Insulin-like growth factor I (IGF$I)$, myogenin (MYOG), myoblast determination factor 1 (myoD1a), myocyte enhancer factor 2A (MEF2A), muscle ring finger protein 1 (MuRF1), muscle-specific $X$ box protein $(M A F b x)$, myosin heavy chain $(M H C)$, myosin light chain 2 (MLC2), pyruvate kinase (PKM), phosphoglycerate kinase $(P G K)$, transaldolase (TALDO1), fructose 1,6 bisphosphatase (FBP1), Aldolase B (ALDOB), cyclic AMP response element binding protein (CrebA), lipoprotein lipase (LPL), diacylglycerol O-acyltransferase homolog 1 (DGAT1), and adiponectin (ADIPOQ).

\section{Quantitative PCR}

qPCR was performed using a Stratagene MX3005P QPCR system (Stratagene, La Jolla, CA, USA) with SYBR green chemistry (Power SYBR, Applied Biosystems, Foster City, CA, USA). cDNA used in qPCR assays was first diluted 80fold with nuclease free water. Each qPCR reaction mixture contained $7.5 \mu \mathrm{l} 1 \times$ Power SYBR green master mix, $6 \mu \mathrm{l}$ cDNA (80-fold dilution), $500 \mathrm{nM}$ each primer and RNase free water to a final volume of $15 \mu$ l. Amplification was performed duplicate in 96 well plates (Stratagene, La Jolla, CA, USA) with the following thermal cycling conditions: initial activation $95^{\circ} \mathrm{C} 10$ minutes, followed by 40 cycles of $15 \mathrm{~s}$ at $95^{\circ} \mathrm{C}, 30 \mathrm{~s}$ at $60^{\circ} \mathrm{C}$, and $30 \mathrm{~s}$ at $72^{\circ} \mathrm{C}$. Dissociation analysis of the PCR products was performed by running a gradient from 60 to $95^{\circ} \mathrm{C}$ to confirm the presence of a single PCR product. Products were also sequenced to confirm identity. A dilution series made from known concentrations of plasmid containing the PCR inserts was used to calculate absolute copy numbers for each of the genes examined.

Standards for calculating absolute copy number for each gene were prepared by cloning the PCR product from each primer pair into a T/A pCR4-TOPO vector (Invitrogen, Carlsbad, CA, USA) and transformation of chemically competent TOP10 Escherichia coli cells (Invitrogen,. Carlsbad, CA, USA). Individual colonies were grown and plasmids purified using Fastprep plasmid purification method (Eppendorf, Hamburg, Germany). The concentration of each plasmid was calculated based on absorbance at $260 \mathrm{~nm}$, and a four fold dilution series produced for calculation of copy number via qPCR. The $r^{2}$ values and qPCR efficiencies based on the plasmid standards dilution series are given in table 1.

\section{Data analysis}

Genorm [43] was used to analyse the stability of several reference genes including $18 S$ Ribosomal RNA, hypoxanthine phosphoribosyltransferase 1 (HPRT1), -actin, RNA polymerase II and Elongation factor 1- (EF1-). Analysis revealed HPRT1, RNA polymerase II and -actin to be the 
Table I: Summary of parameters for qPCR genes studied.

\begin{tabular}{|c|c|c|c|c|c|c|}
\hline Gene & Primer 5'-3' & Prod. size (bp) & $\operatorname{Tm}\left({ }^{\circ} \mathrm{C}\right)$ & $E(\%)$ & $\mathrm{R}^{2}$ & Accession number \\
\hline \multirow[t]{2}{*}{ IGF-I } & f:CCTGTTCGCTAAATCTCACTTC & 226 & 80.3 & 100.3 & 0.998 & EF432852 \\
\hline & r:TACAGCACATCGCACTCTTGA & & & & & \\
\hline \multirow[t]{2}{*}{ Myogenin } & f:GTGGAGATCCTGAGGAGTGC & 146 & 84.5 & 95 & 0.993 & DQ294029 \\
\hline & r:CTCACTCGACGACGAGACC & & & & & \\
\hline \multirow[t]{2}{*}{ MyoDla } & f;CCAAATAGTTCCAGACGCAAG & 104 & 79.8 & 102.1 & 0.999 & AJ557|48 \\
\hline & r:ACAGCGGGACAGGCAGAGG & & & & & \\
\hline \multirow[t]{2}{*}{ MEF2A } & f:ACCGGCTACAACACCGAGTA & 121 & 84.1 & 92.5 & 0.994 & DY7I3536 \\
\hline & r:CCTGGCCCAGTTGATGTT & & & & & \\
\hline \multirow[t]{2}{*}{ MuRFI } & f:AGGCGGGATCAGAGCTAAC & 229 & 87.2 & 103.7 & 0.998 & DNI65465 \\
\hline & r:CGACCATTCCAAAGTCCATC & & & & & \\
\hline \multirow[t]{2}{*}{ MAFbx } & f:AAAGGAAGCACTAAAGAGCGTC & 137 & 83.6 & 97.2 & 0.996 & $\underline{D N 165813}$ \\
\hline & r:CTGGGACTTGGCAATGAGC & & & & & \\
\hline \multirow[t]{2}{*}{ Pkm } & f:GTGACCATGATGCACTCGATC & 225 & 84.6 & 100.3 & 0.992 & CK88837I \\
\hline & r:GGACAGCGTGGGCGATAC & & & & & \\
\hline \multirow[t]{2}{*}{ Pgk } & f:CTCGGTGATGGGGCTTAGG & 160 & 82.6 & 92.1 & 0.996 & DNI66327 \\
\hline & r:TCATTGGTGGAGGCGACA & & & & & \\
\hline \multirow[t]{2}{*}{ TALDOI } & f:AGGTAGACGCCAGGCTTTC & 125 & 82.4 & 99 & 0.994 & EG912503 \\
\hline & r:CCATGTTGAGGAGAGCTTGA & & & & & \\
\hline \multirow[t]{2}{*}{ FBPI } & f:TGGGATTGCCAACCTCTATG & 153 & 81.3 & 96.9 & 0.996 & EG896159 \\
\hline & r:GCCCTCTCGTTCTCCTCTG & & & & & \\
\hline \multirow[t]{2}{*}{ ALDOB } & f:TCCGTGACCTCCTGTTCTCT & 159 & 83.5 & 102.1 & 0.998 & AF067796 \\
\hline & r:CTGTGCCTTTGTCCACCTTA & & & & & \\
\hline \multirow[t]{2}{*}{ CrebA } & f:GGAGTCTGTTTCGCTAAGTCG & 168 & 84.1 & 100.1 & 0.998 & CU073780 \\
\hline & r:CGTAGGACCGCTGGATGT & & & & & \\
\hline \multirow[t]{2}{*}{ LPL } & f:TGCTGGTAGCGGAGAAAGACAT & 114 & 80.8 & 95.9 & 0.998 & BI468076 \\
\hline & r:CTGACCACCAGGAAGACACCAT & & & & & \\
\hline \multirow[t]{2}{*}{ ADIPOQ } & $\mathrm{f}:$ CCAGCCAGAAGGCAATGTAT & 192 & 81.2 & 98.6 & 0.996 & EG776984 \\
\hline & r:CACCAACGACTCCACCTTC & & & & & \\
\hline \multirow[t]{2}{*}{$\mathrm{MHC}$} & $\mathrm{f}: G C A C G C C A C T G A A A A C$ & 209 & 84.1 & 94.2 & 0.996 & DNI64736 \\
\hline & $\mathrm{r}:$ CCTCAAGGTCGTCCACT & & & & & \\
\hline \multirow[t]{2}{*}{ DGATI } & f:CATGCTGGAGGTGATG & 222 & 80.1 & 96.5 & 0.998 & DW564359 \\
\hline & r:GGAAGCACAGTGTGACTGA & & & & & \\
\hline \multirow[t]{2}{*}{ MLC2 } & f:TCAACTTCACCGTCTTCCTCAC & 194 & 82.6 & 98.5 & 0.994 & NM 001123716 \\
\hline & r:GCCCACAGGTTCTTCATCTCC & & & & & \\
\hline \multirow[t]{2}{*}{$\mathrm{EFI}-\alpha$} & fATCGGCTATGCCTGGTGAC & $|4|$ & 85 & 96.3 & 0.999 & BG933853 \\
\hline & r:ATGATGACCTGAGCGGTG & & & & & \\
\hline \multirow[t]{2}{*}{ B-actin } & fACCCAGATCATGTTTGAGACC & 146 & 82.9 & 92.7 & 0.997 & G933897 \\
\hline & r:TCGTAGATGGGTACTGTGTGGG & & & & & \\
\hline \multirow[t]{2}{*}{ RNA pol II } & f:TACATGACCAAATATGAAAGG & 157 & 84.5 & 94.6 & 0.998 & BG936649 \\
\hline & r:GATGATGGGGATCTTCCTGC & & & & & \\
\hline \multirow[t]{2}{*}{ HPRTI } & f:CCTCAAGAGCTACTGTAAT & 255 & 80.8 & 93.6 & 0.997 & $\underline{E G 866745}$ \\
\hline & r:TCTGGAACCTCAAACCCTATG & & & & & \\
\hline \multirow[t]{2}{*}{185} & f:GCGTCCAACTTCTTA & 189 & 85.7 & 95.3 & 0.998 & A]427629 \\
\hline & r:CAATCCССАAТCССТАТC & & & & & \\
\hline
\end{tabular}

Forward and reverse primer sequences ( $\left.5^{\prime}-3^{\prime}\right)$, amplicon product size in base pairs (bp), melting temperature of amplicon (Tm), PCR efficiency (E), regression analysis of plasmid dilution series $\left(R^{2}\right)$ and accession numbers for genes used in $\mathrm{qPCR}$.

most stable genes in this experimental system $(M=0.41)$, thus the geometric average of these genes was used for normalisation of qPCR data. Statistical analysis was performed using minitab (Minitab Inc). Significant differences in expression between time points were calculated by ANOVA using Fisher's individual error rate post hoc tests. Correlations in gene expression were calculated using linear regression and Pearson's correlation. Hierarchical clustering was performed using Cluster3 software [44].

\section{Results}

\section{Fish Growth characteristics}

Prior to fasting, fish had an average mass of $1327 \mathrm{~g} \pm$ $336.1 \mathrm{~g}$ (Mean $\pm \mathrm{SD}, \mathrm{n}=55)$, which after fasting for 32 days, had reduced by an average of $91.2 \pm 23.1 \mathrm{~g}$ (Fig. 1), with an average TGC of $-1.0 \pm 0.14$. After feeding, weight gains were $58.4 \pm 18.3 \mathrm{~g}, 100.6 \pm 38.7 \mathrm{~g}, 125.4 \pm 66.6 \mathrm{~g}$ and $387.6 \pm 114.3 \mathrm{~g}$ for days $3,7,14$ and 32 respectively $(n=10)$. Early TGC calculations are unreliable as the food present in the gut gives a false indication of growth 


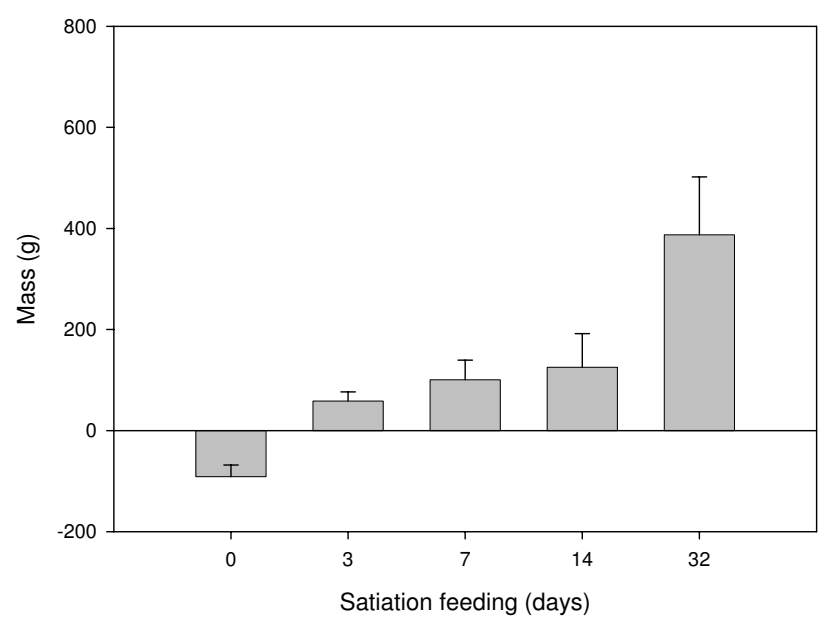

Figure I

Change in body mass over the time course of the experiment. Fish were fasted for 32 days, and then fed to satiation with a commercial fish feed (EWOS Innovation).

Values represent mean \pm S.D., $\mathrm{n}=8$ per sample point. The mass of fish at day 0 was $1327 \mathrm{~g} \pm 336$. $1 \mathrm{~g}$, (Mean $\pm \mathrm{SD}, \mathrm{n}=$ 55)

whereas the later time points provide a more reliable estimate. The TGC for fish (when calculated from weight at the start of feeding, day 0) was mean $3.1 \pm 1.1, \mathrm{n}=8$ at 14 $\mathrm{d}$ and mean $3.7 \pm 0.8, \mathrm{n}=8$ at $32 \mathrm{~d}$. At day 3 , there was an initial increase in weight of $58.4 \pm 18.3 \mathrm{~g}$, contributed by the presence of food in the gut. If this value is subtracted from the later time points, then actual weight gain for days 7,14 and 32 are $42.2 \pm 24.9 \mathrm{~g}, 67.0 \pm 48.1 \mathrm{~g}$ and $329.2 \pm 114.2 \mathrm{~g}$.

\section{Gene expression}

\section{Overview}

A summary heat map and hierarchical clustering of gene expression patterns during fasting-induced recovery growth is shown in Fig. 2. Three main clusters of gene expression were identified. Cluster I comprised $A L D O B$, DGAT1 and $L P L$ which had peak expression at 3-14d after refeeding (Fig. 2). Cluster II comprised ADIPOQ, MLC2, IGF-I and TALDO1 which were later responding showing peak expression 14-32d after refeeding (Fig. 2). In this cluster MLC2 also showed high transcript levels in fasted fish (Fig. 2). Cluster III contained the largest number of genes (MuRF1, MAFbx, CrebA, MYOG, MEF2A, FBP1, PGK, PKM, MHC and MyoD1a) which were mostly up-regulated in fasted fish and generally down regulated with refeeding (Fig. 2).

\section{Muscle-specific ubiquitin ligases}

Both the muscle specific E3 ubiquitin ligases, MuRF1 and $M A F b x$ were significantly down regulated at all time points in fed relative to the fasted fish $(\mathrm{P}<0.01$, Fig. 3A,

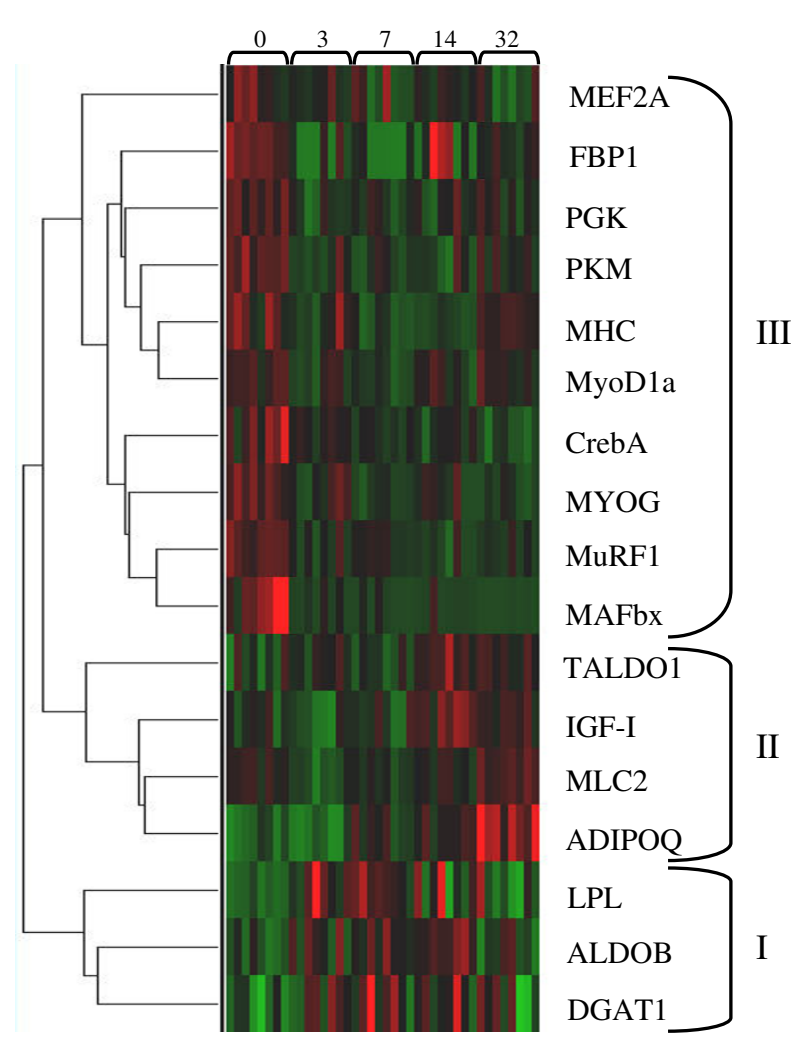

Figure 2

Heat map summary and hierarchical clustering of gene expression patterns during refeeding of fasted (day 0) Atlantic salmon from 3 to 32 days. Spearman rank correlation method using the Cluster 3 program was used for hierarchical clustering. Rows are standardised to have a mean of 0 and s.d of I, so that red indicates high, green low and black values equal to zero. Based on expression patterns, 4 gene clusters were identified. Cluster I comprised genes which had peak expression at 3-I4d after refeeding. Cluster II comprised genes showing peak expression I4-32d after refeeding. Cluster III contained genes which had high expression in fasted fish and mostly down regulation throughout refeeding.

B). MAFbx transcript levels were down regulated up to 98\% (Fig. 3B)

\section{IGF-I}

Transcripts of IGF-I in fast muscle were similar in fasted fish and $3 \mathrm{~d}, 7 \mathrm{~d}$ and $32 \mathrm{~d}$ after feeding, but were significantly upregulated by $142 \%$ at $14 \mathrm{~d}(\mathrm{P}<0.05)$ compared to the $0 \mathrm{~d}$ sample (Fig. 3C)

\section{Myogenic regulatory factors}

The myoD family of transcription factors regulate the commitment of myoblasts to the myogenic lineage (myoD) and muscle differentiation (MYOG) [45]. MYOG expression decreased significantly between the 0 and $7 \mathrm{~d}$ 

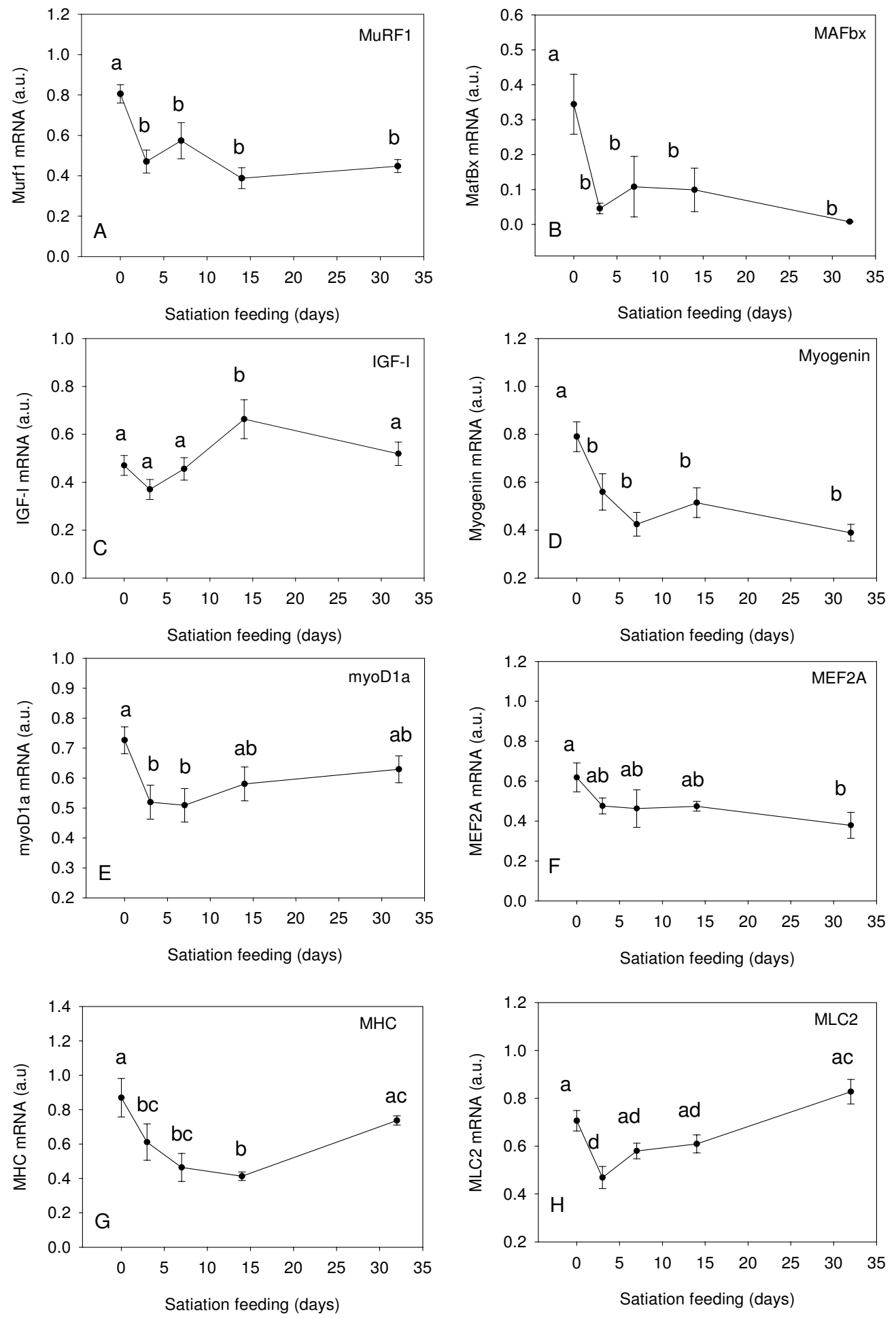

Figure 3

Expression profiles for MuRFI(A), MAFbx (B), IGF-I (C), MYOG (D), myoD Ia (E), MEF2A (F), MHC (G) and MLC2 $(H)$ in fast muscle of Atlantic salmon from fasted fish $(0 \mathrm{~d})$, fed to satiation at $3 \mathrm{~d}, 7 \mathrm{~d}, 14 \mathrm{~d}, 32 \mathrm{~d}$. Gene expression was normalised to the geometric average of three reference genes (Genorm analysis), see text for details. Values represent mean \pm S.E., 8 fish per sample point. Significant differences between means are indicated by different letters. 
samples $(\mathrm{P}<0.01)$ and then remained relatively constant with refeeding (Fig. 3D). There are three retained paralogues of myoD1 in Atlantic salmon each with distinct expression patterns during development and in different fibre types [46]. MyoD1a is the paralogue predominantly expressed in fast skeletal muscle [47]. MyoD1a was upregulated with fasting and showed only minor differences between the fed samples (Fig. 3E). The myocyte-enhancer 2 gene family (MEF2) proteins act co-operatively with myoD proteins to regulate myogenesis [48]. MEF2A transcripts were upregulated in starved individuals and tended to decrease with feeding, producing a statistically significant difference after $32 \mathrm{~d}$ ( $\mathrm{p}<0.05$, Fig. 3F).

\section{Myofibrillar proteins}

The primers to myosin heavy chain were designed to conserved regions of the protein and could potentially amplify multiple isoforms of the $M H C$ transcripts in fast muscle. Expression of this gene(s) was relatively high in fasted fish and significantly decreased $0-14 d(P<0.05)$ after feeding before increasing to $84 \%$ of fasted levels after 32 d (Fig 3G). Myosin light chain 2 significantly decreased $(\mathrm{P}<0.01)$ an average $66 \%$ between fasted fish and the $3 \mathrm{~d}$ feeding sample before increasing to reach $117 \%$ of day 0 levels in the $32 \mathrm{~d}$ sample (Fig. $3 \mathrm{H}$ ), although this increase was not statistically significant.

\section{Metabolic genes}

Transcripts for PKM (Fig. 4A) and PGK (Fig. 4B) decreased by $50 \%$ between the fasted and 3 d sample $(\mathrm{p}<0.05)$ and showed no further change with feeding. In contrast, levels of TALDO1 transcripts were similar in the fasted, $3 \mathrm{~d}$ and 7 d samples before increasing $141 \%$ at $14 \mathrm{~d}$ and $32 \mathrm{~d}$ ( $\mathrm{p}<$ 0.05 ) (Fig. 4C). FBP1 mRNA was down regulated 69\% at $3 \mathrm{~d}$ and $78 \%$ at $7 \mathrm{~d}(\mathrm{p}<0.05)$ relative to the fasted sample before partially recovering $14 \mathrm{~d}$ and $32 \mathrm{~d}$ after refeeding (Fig. 4D). ALDOB transcripts increased with feeding reaching a peak at $14 \mathrm{~d}$ which was significantly higher than in fasted fish $(\mathrm{P}=0.05)$ (Fig. $4 \mathrm{E})$. CrebA was down regulated $38 \%$ between the fasted and $3 \mathrm{~d}$ fed sample $(\mathrm{p}<$ 0.05 ) and showed a further $69 \%$ decline by the $32 \mathrm{~d}$ sample (Fig. 4F). PKM expression was positively correlated with expression of MuRF1 $\left(\mathrm{r}^{2}=0.69, \mathrm{P}<0.0001, \mathrm{r}=0.71\right.$; Figure 5).

\section{Genes involved in lipid metabolism and adipocyte differentiation} Expression of DGAT1 showed a small increase over fasting levels after $3 \mathrm{~d}$ of feeding and remained at this level throughout the experiment, although this increase was not statistically significant (Fig. 6A). Expression of LPL was significantly upregulated at $3 \mathrm{~d}$, expression then decreased at $7 \mathrm{~d}$ and $14 \mathrm{~d}$ and returned to near day 0 values at $32 \mathrm{~d}$ (Fig. 6B). ADIPOQ transcript levels were significantly increased at $7 \mathrm{~d}, 14 \mathrm{~d}$ and $32 \mathrm{~d}$ compared to fasted fish (Fig. 6C). ADIPOQ was positively correlated with expression of MLC2 at all time points $\left(r^{2}=0.35 \mathrm{p}=0.003\right.$, $r=0.60$, Fig. 7A) and even higher correlation at fed time points ( $3 \mathrm{~d}, 7 \mathrm{~d}, 14 \mathrm{~d}, 32 \mathrm{~d})\left(\mathrm{r}^{2}=0.48 \mathrm{p}<0.0001, \mathrm{r}=0.69\right.$, Fig. 7B)

\section{Discussion}

Atlantic salmon continue to grow throughout their life cycle. It is known that muscle fibres are continuously produced until $\sim 2 \mathrm{~kg}$ body mass, after which growth only involves fibre hypertrophy and associated nuclear accretion [49]. Thus salmon of the size studied show active myogenesis. A $32 \mathrm{~d}$ fast at $8^{\circ} \mathrm{C}$, resulted in negative growth (TGC $=-1.0$ ) corresponding to a $6.9 \%$ decrease in body mass (Fig. 1). Following satiation refeeding, there was an average weight gain of $5.4 \%$ and $26.7 \%$ after $14 \mathrm{~d}$ and $32 \mathrm{~d}$ respectively. The myofibrillar proteins, principally actin and myosin, are a major source of the amino acids mobilised during fasting and migration in salmonids and comprise two thirds of the total protein content of fast muscle [50]. In the present study, mRNA transcripts for MHC and MLC2 decreased as an early response to feeding as reported earlier for Atlantic salmon undergoing a transition from zero to fast growth [29]. Expression of both these genes increased markedly by $32 \mathrm{~d}$ refeeding, with MLC2 expression exceeding that at $0 \mathrm{~d}$ (Fig. $3 \mathrm{H}$ ).

Mammals respond to muscle wasting conditions, such as starvation, with the transcriptional upregulation of the ubiquitin ligases MuRF1 and MAFbx [51]. These proteins function in the ubiquitinisation of contractile proteins including troponin I [52] and myosin [53,54]. Furthermore, decreased MAFbx leads to an increase in the translation regulator eif3-f [38]. In the present study, we found that expression of the E3 ubiquitin ligases $M A F b x$ and $M u R F 1$ were also elevated in fasted Atlantic salmon and that both were significantly and strongly down regulated in response to feeding (Fig. 3A, B). MAFbx formed a cluster with MuRF1, MYOG and CrebA, which had strong down regulation at all time points following refeeding and with myod1a, MHC, PKM, PGK, FBP1 and MEF2A, which were also down regulated but not as strongly, following refeeding (Fig. 2). A reduction in protein degradation through down regulation of $M u R F 1$, together with a concomitant increase in translational efficiency mediated by $M A F b x$ may well allow the replacement of myosin mobilised during fasting much earlier than indicated by changes in transcript levels.

During fasting in mammals, glucagon release causes an increase in cAMP levels, activating the transcription factor CrebA [55], which induces the expression of genes involved in gluconeogenesis [56]. Due to the presence of cyclic AMP response elements in the promoter of CrebA, expression of CrebA is induced in a positive feedback mechanism [57]. In the present study, expression of CrebA 

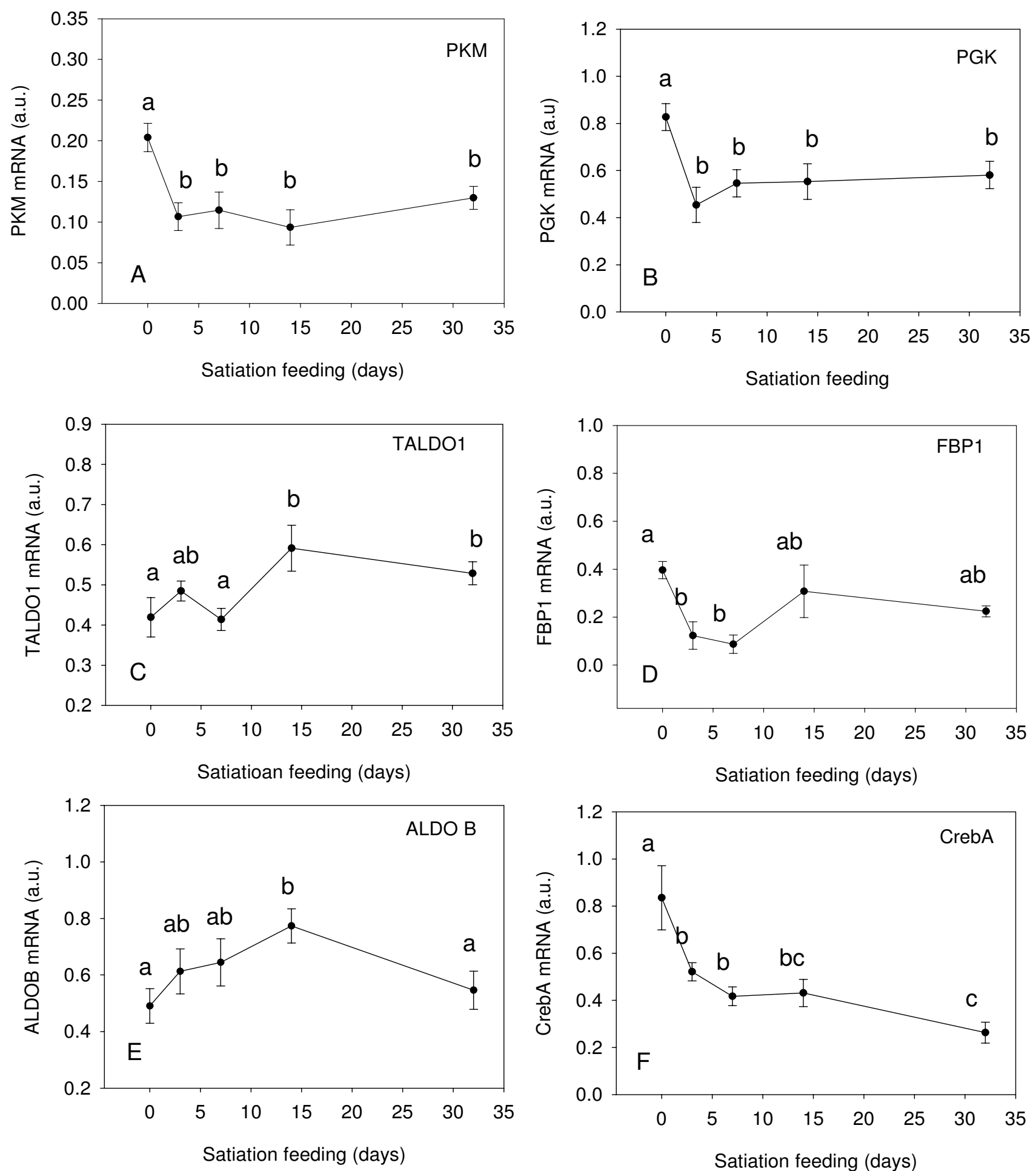

Figure 4

Expression profiles for PKM (A), PGK (B), TALDOI (C), FBPI (D), ALDOB (E) and CrebA (F) in fast muscle of Atlantic salmon from fasted fish $(\mathbf{0 ~ d})$, fed to satiation at $3 \mathrm{~d}, \mathbf{7} \mathrm{d}, \mathbf{1 4} \mathrm{d}, 32 \mathrm{~d}$. Gene expression was normalised to the geometric average of three reference genes (Genorm analysis), see text for details. Values represent mean \pm S.E., 8 fish per sample point. Significant differences between means are indicated by different letters. 


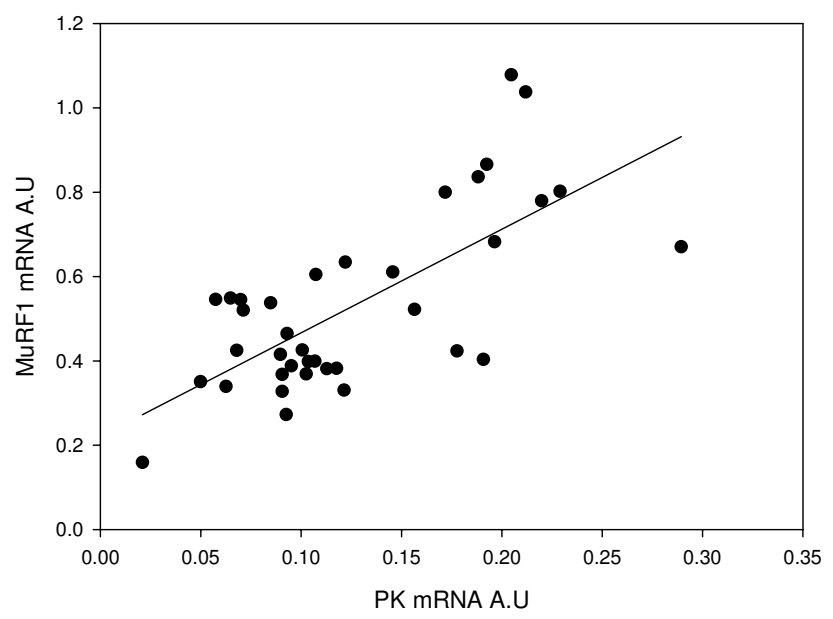

Figure 5

Correlation between MuRFI and PKM mRNA ( $r^{2}=$ $0.50, p<0.0001, n=32$ ).

was significantly down regulated in response to feeding as was FBP1 consistent with relatively high levels of gluconeogenesis occurring with fasting and a reduction in gluconeogenic activity with feeding.

In mammals, MuRF1 has been shown to decrease the abundance of certain glycolytic enzymes [39]. Thus in fasted fish elevated levels of MuRF1 might be expected to lead to a reduction in the flux through the glycolytic pathway. However, we found that the mRNAs for PKM and $P G K$ were highest in fasted fish and decreased with feeding (Fig. 4). Interestingly, expression of PKM and MuRF1 were correlated $\left(\mathrm{r}^{2}=0.48, \mathrm{P}<0.0001, \mathrm{r}=0.71\right.$; Fig 5$)$. It is possible that the elevated levels of PKM and PGK transcripts in fasted fish represent a response to decreased flux through the glycolytic pathway due to MuRF1 inhibition. Decreased flux through the glycolytic pathway could result in elevated levels of glucose which is a potent stimulator of PKM expression [58]. Johansen and Overturf [59] also found that expression of PKM increased during starvation and suggested that this increase was a requirement for the catabolisation of certain amino acids.

An alternative fate for the increased glucose present with feeding is to enter the pentose phosphate pathway [60]. TALDO1 is a key regulator of the pentose phosphate pathway, responsible for the generation of NADPH required for fatty acid synthesis, and ribose-5-phosphate required for nucleotide and nucleic acid synthesis [61,62]. Increased expression of TALDO1 is indicative of activation of the pentose phosphate pathway. Increased flux through this pathway could provide ribose-5-phosphate required for nucleotide production during the period of rapid growth with the NADPH used for fatty acid synthe-
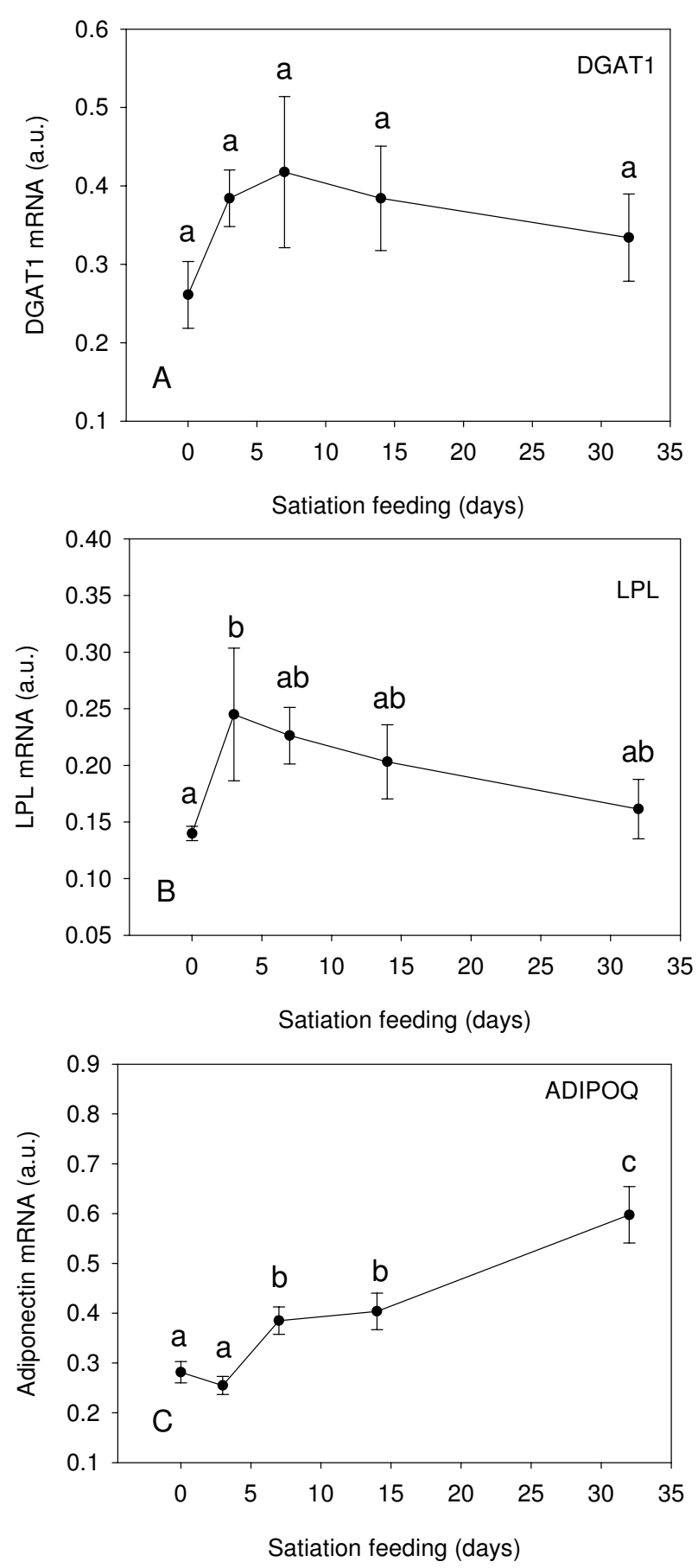

Figure 6

Expression profiles for DGATI (A), LPL (B) and ADI$P O Q(C)$ in fast muscle of Atlantic salmon from

fasted fish (0 d), fed to satiation at $3 \mathrm{~d}, 7 \mathrm{~d}, 14 \mathrm{~d}, 32 \mathrm{~d}$. Gene expression was normalised to the geometric average of three reference genes (Genorm analysis), see text for details. Values represent mean \pm S.E., 8 fish per sample point. Significant differences between means are indicated by different letters. 
sis to replace the fatty acids used during the period of nutrient restriction. Generation of NADPH is also required to maintain glutathione in a reduced state and protect cellular integrity from reactive oxygen species [63]. The production of reactive oxygen species has been demonstrated to be lower in caloric restricted rats [64]. Increased expression of transaldolase may be required to protect cells from the elevated production of reactive oxygen species with refeeding.

In salmonids, muscle is a major site for fat storage [65]. In Atlantic salmon fast muscle, the fat content makes up $9.6 \%$ of the wet weight, with triacylglycerols contributing $93.3 \%$ of the total lipid content [66]. These reserves are likely to be exhausted during fasting, and must be replenished during periods of feeding. $A L D O B$ is involved in the synthesis of triacylglycerols via the phosphatidic acid pathway [67]. Johanssen and Overturf [59] found that levels of $A L D O B$ were 10 times higher during refeeding than in normal feeding, implying that during fasting-induced recovery growth, higher rates of fatty acid deposition are occurring. Also, Witt et al. [36] identified aldolase as a target for MuRF1, so the elevated levels of MuRF1 could further lead to reduced levels of aldolase in fasted fish.

Analysis of gene expression patterns reveals a cluster of genes (cluster I, Fig. 2) corresponding to triacylglycerol synthesis and adipogenic differentiation, which increase prior to any increases in MRFs or IGF-I (Fig. 2). LPL hydrolyses triglycerides, with the free fatty acids produced available as a direct energy source or used for storage in adipocytes [68]. Together, with the increased aldolase expression, increased LPL expression in the first few days of feeding, suggests TAGs are resynthesised in skeletal muscle to replace those used during the period of nutrient restriction. In Atlantic salmon, high densities of adipocytes are present in the myosepta of white muscle where the majority of lipids are stored as triacylglycerols [69]. We also examined the expression of adiponectin (ADIPOQ), an adipocytokine which increases in expression during differentiation of adipocytes and thus may serve as a marker of adipocyte differentiation [70,71]. Expression of this gene was significantly upregulated from $7 \mathrm{~d}$ after refeeding, indicating that adipogenic differentiation is occurring during these times. The expression of Diacylglycerol:acyl CoA acyltransferase (DGAT1), an enzyme involved in TAG synthesis, was also examined. Expression of DGAT1 increased early in response to feeding and remained elevated. DGAT1 mRNA expression has been shown to increase in differentiating 3T3-L1 adipocytes, with even greater increases in protein activity observed, suggesting that DGAT1 is also post transcriptionally regulated [72]. Although $L P L$ and $A L D O B$ gene expression decreased at day 32, DGAT1 remained elevated indicating that TAG synthesis is still occurring.
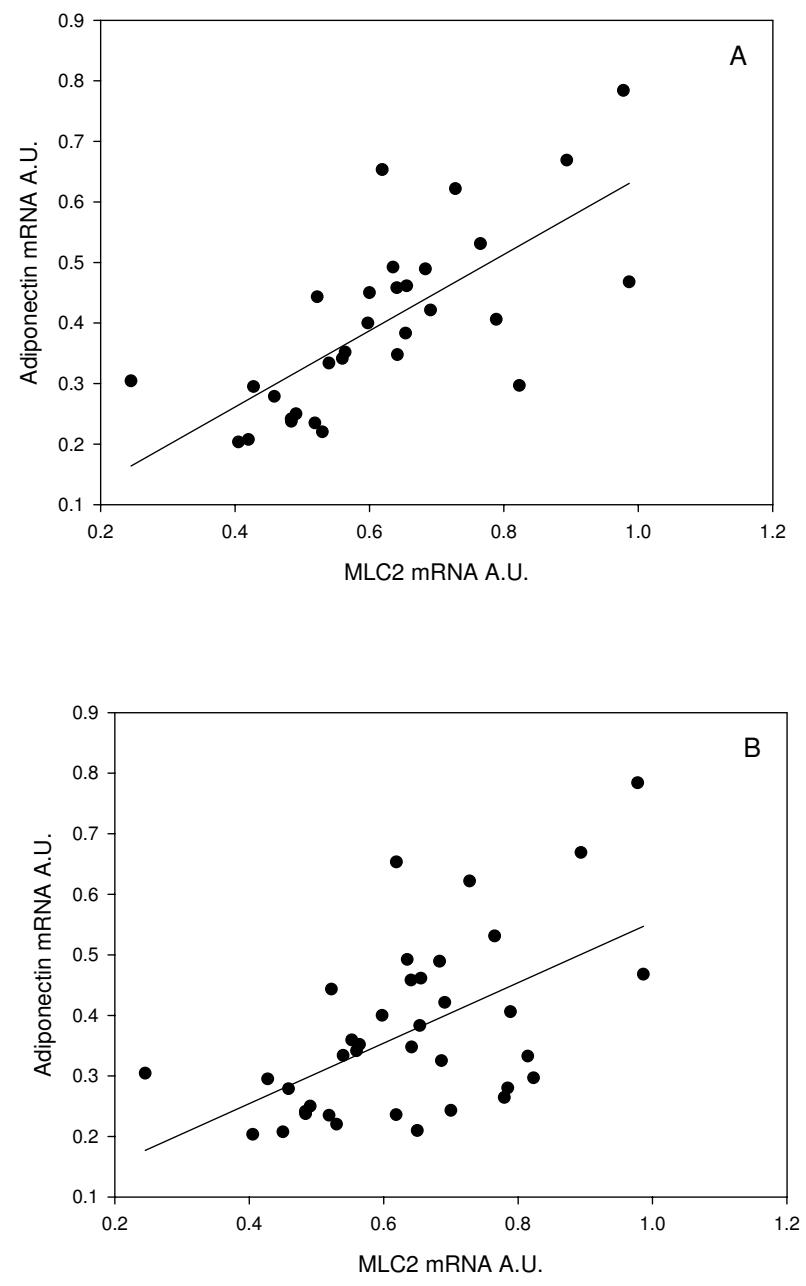

Figure 7

Correlation between MLC2 MRNA and ADIPOQ mRNA at all time points $(A)\left(r^{2}=0.36, p=0.003, r=\right.$ $0.59, n=40$ ), and at fed time points (B) (3 d, $7 \mathrm{~d} / 4 \mathrm{~d}$, $32 \mathrm{~d} ; r^{2}=0.48, p<0.001, r=0.69 n=32$ ).

The decreased expression $A L D O B$ and $L P L$ after $32 \mathrm{~d}$ refeeding coincides with the increased expression of $M L C 2$ and MHC (relative to $3 \mathrm{~d}, 7 \mathrm{~d}$ and $14 \mathrm{~d}$ ). We found a positive correlation between MLC2 and ADIPOQ $\left(\mathrm{r}^{2}=\right.$ $0.35, \mathrm{P}<0.0005, \mathrm{r}=0.59$; Fig. $7 \mathrm{~A})$, which was even greater when only days where food has been ingested are considered $\left(\mathrm{r}^{2}=0.48, \mathrm{P}<0.0001, \mathrm{r}=0.69 ;\right.$ Fig. $\left.7 \mathrm{~B}\right)$. ADIPOQ has been demonstrated to increase sensitivity of myogenic cells to insulin [73]. The mTOR signalling pathway, which regulates protein accretion in skeletal muscle, is regulated by amino acids and insulin in teleost fish [74] so this increased sensitivity to insulin may be necessary for the resumption of myogenesis. Recently, cross talk of signals between skeletal muscle and adipose tissues has been suggested, with the cytokines identified as potentially impor- 
tant regulators maintaining the ratio of skeletal muscle to adipose tissue [75]. Receptors for ADIPOQ have been found to be expressed in zebrafish muscle [76]. Furthermore, myostatin has been shown to inhibit myogenesis and promote adipogenesis in multipotent mesenchymal cells [77]. Additional experiments in Atlantic salmon are required to determine if crosstalk between adipocytes and skeletal muscle is occurring and if this plays any role in regulating the myogenic program following refeeding.

\section{Conclusion}

In conclusion, after a period of fasting, refeeding Atlantic salmon results in changes in metabolism leading to the replacement of lost energy reserves through increased fatty acid deposition and replacement of myofibrillar proteins. Increased myofibrillar protein deposition likely occurs through the down-regulation of MuRF1 and MAFbx leading to decreased protein degradation and increased translation respectively. Both the replacement of myofibrillar proteins and activation of the adipogenic program precede an increase in transcripts for myofibrillar proteins and myogenic regulatory factors. For an animal which is adapted to long periods of food deprivation, such as Atlantic salmon, achieving a state where energy reserves have been replenished, before metabolic energy is directed towards production of new muscle fibres, could be a necessary strategy for long term survival.

\section{Competing interests}

The authors declare that they have no competing interests.

\section{Authors' contributions}

NB performed the experimental work and wrote the first draft of the manuscript. RT was responsible for fish maintenance. IJ contributed to study design and writing of the manuscript. All authors read and approved the final manuscript

\section{Acknowledgements}

All S. salar samples were provided by EWOS Innovation. This work was supported by a grant from the Biotechnology and Biological Research Council grant (BB/DOI539I/I), and grants from the Norwegian Research Council (I 74557 FUGE and I 74222 HAVBRUK) to EWOS Innovation. The authors thank Dr Jorge Fernandes for EFIalpha, RNA pol II and $\beta$ actin primers, and Dr Daniel MacQueen for MLC2 and myoDla primers and standards.

\section{References}

I. Jonsson N, Jonsson B, Hansen LP: Changes in proximate composition and estimates of energetic costs during upstream migration and spawning in Atlantic salmon, Salmo salar. J Anim Ecol 1997, 66:425-436.

2. Brett JR: Production energetic of poulations of sockeye salmon, Oncorhynchus nerka. Can J Zool 1986, 64:555-564.

3. Jones JW: The salmon. London: Collins; 1959.

4. Kadri S, Metcalfe NB, Huntingford FA, Thorpe JE: What Controls the Onset of Anorexia in Maturing Adult Female Atlantic Salmon. Funct Ecol 1995, 9(5):790-797.
5. Semenchencko NN: Assessment of energy expenditure during spawning by male sockeye salmon, Oncorhynchus nerka, at various sex ratios in the spawning ground. J Ichthyol 1986, 26(I):89-97.

6. Jonsson N, Jonsson B, Hansen LP: Energetic Cost of Spawning in Male and Female Atlantic Salmon (Salmo-Salar L). J Fish Biol I99|, 39(5):739-744.

7. Hendry AP, Berg OK, Quinn TP: Breeding location choice in salmon: causes (habitat, competition, body size, energy stores) and consequences (life span, energy stores). Oikos 93:407-4I8.

8. McVeigh BR, Healey MC, Wolfe F: Energy expenditures during spawning by chum salmon Oncorhynchus keta (Walbaum) in British Columbia. J Fish Biol 2007, 7 I (6): 1696-1713.

9. Bardonnet $A$, Bagliniere JL: Freshwater habitat of Atlantic salmon (Salmo salar). Can J Fish Aqua Sci 2000, 57(2):497-506.

10. Talbot C, Preston T, East BW: Body-Composition of Atlantic Salmon (Salmo-Salar L) Studied by Neutron-Activation Analysis. Comp Biochem Physiol A Physiol 1986, 85(3):445-450.

11. Valdimarsson SK, Metcalfe NB, Thorpe JE, Huntingford FA: Seasonal changes in sheltering: effect of light and temperature on diel activity in juvenile salmon. Anim Behav 1997, 54: I405-I4I2.

12. Egglishaw HJ, Shackley PE: Growth, Survival and Production of Juvenile Salmon and Trout in a Scottish Stream, 196675. J Fish Biol 1977, II(6):647-672.

13. Gardiner WR, Geddes P: The Influence of Body-Composition on the Survival of Juvenile Salmon. Hydrobiologia 1980, 69(12):67-72.

14. Rowe DK, Thorpe JE, Shanks AM: Role of Fat Stores in the Maturation of Male Atlantic Salmon (Salmo-Salar) Parr. Can J Fish Aqua Sci 199I, 48(3):405-4I3.

15. Binner M, Kloas W, Hardewig I: Energy allocation in juvenile roach and burbot under different temperature and feeding regimes. Fish Physiol Biochem 2008, 34(2): 103-116.

16. Houlihan DF, Waring CP, Mathers E, Gray C: protein-synthesis and oxygen-consumption of the shore crab Carcinus-Maenas after a meal. Physiol Zool 1990, 63(4):735-756.

17. Peragon J, Barroso JB, Garcia-Salguero L, Aranda F, de la Higuera M, Lupianez JA: Selective changes in the protein-turnover rates and nature of growth induced in trout liver by long-term starvation followed by re-feeding. Mol Cell Biochem 1999, 20I(I2): I-I0.

18. Mommsen TP, French CJ, Hochachka PW: Sites and patterns of protein and amino-acid utilization during the spawning migration of salmon. Can J Zool I 980, 58(10): 1785-1799.

19. Moon TW: Metabolic reserves and enzyme-activities with food-deprivation in immature american eels, Anguilla-Rostrata (Lesueur). Can J Zool I983, 61(4):802-8II.

20. Johnston IA, Davison W, Goldspink G: Energy-metabolism of carp swimming muscles. J Comp Physiol 1977, I I 4(2):203-216.

21. Bone Q, Kiceniuk J, Jones DR: Role of different fiber types in fish myotomes at intermediate swimming speeds. Fish Bull 1978, 76(3):691-699.

22. Johnston IA, Goldspink G: Some effects of prolonged starvation on metabolism of red and white myotomal muscles of plaice Pleuronectes-Platessa. Marine Biology 1973, 19(4):348-353.

23. Beardall $\mathrm{CH}$, Johnston IA: Lysosomal-enzyme activities in muscle following starvation and refeeding in the saithe Pollachius-Virens L. Eur J Cell Biol 1985, 39(I): I I 2-I I7.

24. Jobling $M$ : Bioenergetics: feed intake and energy partitioning. In Fish Ecophysiology Edited by: Rankin JC, Jensen FB. Chapman \& Hall, London; 1993:1-44.

25. Nicieza AG, Metcalfe NB: Growth compensation in juvenile Atlantic salmon: Responses to depressed temperature and food availability. Ecology 1997, 78(8):2385-2400.

26. Chauvigne F, Gabillard JC, Weil C, Rescan PY: Effect of refeeding on IGFI, IGFII, IGF receptors, FGF2, FGF6, and myostatin mRNA expression in rainbow trout myotomal muscle. Gen Comp Endocrinol 2003, I32(2):209-215.

27. Gabillard JC, Kamangar BB, Montserrat N: Coordinated regulation of the GH/IGF system genes during refeeding in rainbow trout (Oncorhynchus mykiss). J Endocrinol 2006, I9I(I): 15-24.

28. Rescan PY, Montfort J, Ralliere C, Le Cam A, Esquerre D, Hugot K: Dynamic gene expression in fish muscle during recovery growth induced by a fasting-refeeding schedule. Bmc Genomics 2007, 8:438. 
29. Bower NI, Li XJ, Taylor R, Johnston IA: Switching to fast growth: the insulin-like growth factor (IGF) system in skeletal muscle of Atlantic salmon. J Exp Biol 2008, 2 I I (24):3859-3870.

30. Montserrat N, Gabillard JC, Capilla E, Navarro Ml, Gutierrez J: Role of insulin, insulin-like growth factors, and muscle regulatory factors in the compensatory growth of the trout (Oncorhynchus mykiss). Gen Comp Endocrinol 2007, I 50(3):462-472.

31. Wood AW, Duan CM, Bern HA: Insulin-like growth factor signaling in fish. Int Rev Cytol a Survey of Cell Biology 2005, 243:2 I5-285.

32. Inoki $\mathrm{K}, \mathrm{Li} \mathrm{Y}, \mathrm{Zhu} \mathrm{TQ}, \mathrm{Wu}$, Guan KL: TSC2 is phosphorylated and inhibited by Akt and suppresses mTOR signalling. Nat Cell Biol 2002, 4(9):648-657.

33. Stitt TN, Drujan D, Clarke BA, Panaro F, Timofeyva Y, Kline WO, Gonzalez M, Yancopoulos GD, Glass D]: The IGF-I/PI3K/Akt pathway prevents short article expression of muscle atrophy-induced ubiquitin ligases by inhibiting FOXO transcription factors. Mol Cell 2004, I 4(3):395-403.

34. Rommel C, Bodine SC, Clarke BA, Rossman R, Nunez L, Stitt TN, Yancopoulos GD, Glass DJ: Mediation of IGF-I-induced skeletal myotube hypertrophy by $\mathrm{PI}(3) \mathrm{K} / \mathrm{Akt} / \mathrm{mTOR}$ and $\mathrm{PI}(3) \mathrm{K} / \mathrm{Akt} /$ GSK3 pathways. Nat Cell Biol 200I, 3(I I): 1009-10I3.

35. Bodine SC, Latres E, Baumhueter S, Lai VKM, Nunez L, Clarke BA, Poueymirou WT, Panaro FJ, Na EQ, Dharmarajan K, Pan ZQ, Valenzuela DM, DeChiara TM, Stitt TN, Yancopoulos GD, Glass DJ: Identification of ubiquitin ligases required for skeletal muscle atrophy. Science 200I, 294(5547): I704-I708.

36. Witt SH, Granzier H, Witt CC, Labeit S: MURF-I and MURF-2 target a specific subset of myofibrillar proteins redundantly: Towards understanding MURF-dependent muscle ubiquitination. J Mol Biol 2005, 350(4):713-722.

37. Holz MK, Ballif BA, Gygi SP, Blenis J: mTOR and S6KI mediate assembly of the translation preinitiation complex through dynamic protein interchange and ordered phosphorylation events. Cell 2005, 123(4):569-580.

38. Lagirand-Cantaloube J, Offner N, Csibi A, Leibovitch MP, BatonnetPichon S, Tintignac LA, Segura CT, Leibovitch SA: The initiation factor elF3-f is a major target for Atrogin I/MAFbx function in skeletal muscle atrophy. $E M B O$ J 2008, 27(8): |266- 1276.

39. Hirner S, Krohnelt C, Schuster A, Hoffmann S, Witt S, Erber R, Sticht C, Gasch A, Labeit S, Labeit D: MuRFI-dependent regulation of systemic carbohydrate metabolism as revealed from transgenic mouse studies. J Mol Biol 2008, 379(4):666-677.

40. Tintignac LA, Lagirand J, Batonnet S, Sirri V, Leibovitch MP, Leibovitch SA: Degradation of MyoD mediated by the SCF (MAFbx) ubiquitin ligase. I Biol Chem 2005, 280(4):2847-2856.

4I. Bustin SA, Benes V, Garson JA, Hellemans J, Huggett J, Kubista M, Mueller R, Nolan T, Pfaffl MW, Shipley GL, Vandesompele J, Wittwer CT: The MIQE Guidelines: Minimum Information for Publication of Quantitative Real-Time PCR Experiments. Clin Chem 2009, 55(4):6II-622.

42. Kleveland El, Ruyter B, Vegusdal A, Sundvold H, Berge RK, Gjoen T: Effects of 3-thia fatty acids on expression of some lipid related genes in Atlantic salmon (Salmo salar L. Comp Biochem Physiol B Biochem Mol Biol 2006, I 45(2):239-248.

43. Vandesompele J, De Preter K, Pattyn F, Poppe B, Van Roy N, De Paepe A, Speleman F: Accurate normalization of real-time quantitative RT-PCR data by geometric averaging of multiple internal control genes. Genome Biol 2002, 3(7):RESEARCH0034.

44. de Hoon MJL, Imoto S, Nolan J, Miyano S: Open source clustering software. Bioinformatics 2004, 20(9): | 453-1454.

45. Molkentin JD, Olson EN: Defining the regulatory networks for muscle development. Current Opinion in Genetics \& Development 1996, 6(4):445-453.

46. Macqueen $D J$, Robb $D$, Johnston IA: Temperature influences the coordinated expression of myogenic regulatory factors during embryonic myogenesis in Atlantic salmon (Salmo salar L. J Exp Biol 2007, 21 0:2781-2794.

47. Macqueen DJ, Johnston IA: A novel salmonid myoD gene is distinctly regulated during development and probably arose by duplication after the genome tetraploidization. FEBS Lett 2006, 580(2I):4996-5002.

48. Berkes CA, Tapscott SJ: MyoD and the transcriptional control of myogenesis. Seminars in Cell \& Developmental Biology 2005, 16(45):585-595
49. Johnston IA, Manthri S, Alderson R, Smart A, Campbell P, Nickell D, Robertson B, Paxton CGM, Burt ML: Freshwater environment affects growth rate and muscle fibre recruitment in seawater stages of Atlantic salmon (Salmo salar L. J Exp Biol 2003, 206(8): $|337-| 35 \mid$

50. Mommsen TP: Paradigms of growth in fish. Comparative Biochemistry and Physiology B-Biochemistry \& Molecular Biology 200I, 129(23):207-219.

5I. Koyama S, Hata S, Witt CC, Ono Y, Lerche S, Ojima K, Chiba T, Do N, Kitamura F, Tanaka K, Abe K, Witt SH, Rybin V, Gasch A, Franz T, Labeit S, Sorimachi H: Muscle RING-finger protein-I (MuRFI) as a connector of muscle energy metabolism and protein synthesis. J Mol Biol 2008, 376(5): I224-I236.

52. Kedar V, McDonough H, Arya R, Li HH, Rockman HA, Patterson C: Muscle-specific RING finger $I$ is a bona fide ubiquitin ligase that degrades cardiac troponin I. Proc Natl Acad Sci USA 2004, IOI(52): $|8| 35-|8| 40$.

53. Glass DJ: Skeletal muscle hypertrophy and atrophy signaling pathways. Int J Biochem Cell Biol 2005, 37( 1 0): I 974-1984.

54. Clarke BA, Drujan D, Willis MS, Murphy LO, Corpina RA, Burova E, Rakhilin SV, Stitt TN, Patterson C, Latres E, Glass DJ: The E3 ligase MuRFI degrades myosin heavy chain protein in dexamethasone-treated skeletal muscle. Cell Metab 2007, 6:376-385.

55. Daniel PB, Walker WH, Habener JF: Cyclic AMP signaling and gene regulation. Annu Rev Nutr 1998, 18:353-383.

56. Herzig S, Long FX, Jhala US, Hedrick S, Quinn R, Bauer A, Rudolph D, Schutz G, Yoon C, Puigserver P, Spiegelman B, Montminy M: CREB regulates hepatic gluconeogenesis through the coactivator PGC-I. Nature 200I, 4I3(6852): 179-183.

57. Meyer TE, Waeber G, Lin J, Beckmann W, Habener JF: The promoter of the gene encoding 3',5'-cyclic adenosine-monophosphate (camp) response element binding-protein contains camp response elements evidence for positive autoregulation of gene-transcription. Endocrinology 1993, 132(2):770-780.

58. Yamada E, Noguchi T: Regulation of pyruvate kinase $M$ gene expression. Biochem Biophys Res Commun 1999, 256(2):257-262.

59. Johansen KA, Overturf $\mathrm{K}$ : Alterations in expression of genes associated with muscle metabolism and growth during nutritional restriction and refeeding in rainbow trout. Comp Biochem Physiol B Biochem Mol Biol 2006, I 44(I): I I9-127.

60. Bouche C, Serdy S, Kahn CR, Goldfine AB: The cellular fate of glucose and its relevance in type 2 diabetes. Endocr Rev 2004, 25(5):807-830

6I. Patel MS, Jomainba M, Ballard FJ, Hanson RW: Pathway of carbon flow during fatty acid synthesis from lactate and pyruvate in rat adipose tissue. J Lipid Res 1971, I2(2): 179-191.

62. Boss GR, Pilz RB: Phosphoribosylpyrophosphate synthesis from glucose decreases during amino-acid starvation of human-lymphoblasts. J Biol Chem I 985, 260( I 0):6054-6059.

63. Banki K, Hutter E, Colombo E, Gonchoroff NJ, Perl A: Glutathione levels and sensitivity to apoptosis are regulated by changes in transaldolase expression. I Biol Chem 1996, 27 I (5 I):32994-3300 I

64. Gredilla R, Sanz A, Lopez-Torres M, Barja G: Caloric restriction decreases mitochondrial free radical generation at complex I and lowers oxidative damage to mitochondrial DNA in the rat heart. FASEB J 200I, I 5(7): I589-159|.

65. Polvi SM, Ackman RG: Atlantic Salmon (Salmo-Salar) muscle lipids and their response to alternative dietary fatty-acid sources. J Agric Food Chem 1992, 40(6): 100 I-1007.

66. Aursand M, Bleivik B, Rainuzzo JR, Jorgensen L, Mohr V: Lipid distribution and composition of commercially farmed atlantic salmon (Salmo-Salar). Sci Food Agric 1994, 64(2):239-248.

67. Lehner R, Kuksis A: Biosynthesis of triacylglycerols. Prog Lipid Res 1996, 35(2): 169-20I.

68. Auwerx J, Leroy P, Schoonjans K: Lipoprotein-lipase recent contributions from molecular-biology. Crit Rev Clin Lab Sci 1992, 29(34):243-268.

69. Nanton DA, Vegusdal A, Rora AMB, Ruyter B, Baeverfjord G Torstensen BE: Muscle lipid storage pattern, composition, and adipocyte distribution in different parts of Atlantic salmon (Salmo salar) fed fish oil and vegetable oil. Aquaculture 2007, 265(14):230-243 
70. Fu YC, Luo NL, Klein RL, Garvey WT: Adiponectin promotes adipocyte differentiation, insulin sensitivity, and lipid accumulation. J Lipid Res 2005, 46(7):1369-1379.

71. Korner A, Wabitsch M, Seidel B, Fischer-Posovszky P, Berthold A, Sturnvoll M, Bluher M, Kratzsch E, Kiess W: Adiponectin expression in humans is dependent on differentiation of adipocytes and down-regulated by humoral serum components of high molecular weight. Biochem Biophys Res Commun 2005, 337(2):540-550.

72. Yu YH, Zhang YY, Oelkers P, Sturley SL, Rader DJ, Ginsberg HN: Posttranscriptional control of the expression and function of diacylglycerol acyltransferase- $I$ in mouse adipocytes. J Biol Chem 2002, 277(52):50876-50884.

73. Wang CH, Mao XM, Wang LX, Liu ML, Wetzel MD, Guan KL, Dong $L Q$, Liu F: Adiponectin sensitizes insulin signaling by reducing p70 S6 kinase-mediated serine phosphorylation of IRS-I. J Biol Chem 2007, 282(I I):799I-7996.

74. Seiliez I, Gabillard JC, Skiba-Cassy S, Garcia-Serrana D, Gutierrez J, Kaushik S, Panserat $S$, Tesseraud $S:$ An in vivo and in vitro assessment of TOR signaling cascade in rainbow trout (Oncorhynchus mykiss). Am J Physiol Regul Integr Comp Physiol 2008, 295(I):R329-R335.

75. Argiles JM, Lopez-Soriano J, Almendro V, Busquets S, Lopez-Soriano FJ: Cross-talk between skeletal muscle and adipose tissue: $\mathbf{A}$ link with obesity? Med Res Rev 2005, 25(I):49-65.

76. Nishio Sl, Gibert Y, Bernard L, Brunet F, Triqueneaux G, Laudet V: Adiponectin and adiponectin receptor genes are coexpressed during zebrafish embryogenesis and regulated by food deprivation. Dev Dyn 2008, 237(6): 1682-1690.

77. Artaza JN, Bhasin S, Magee TR, Reisz-Porszasz S, Shen RQ, Groome NP, Fareez MM, Gonzalez-Cadavid NF: Myostatin inhibits myogenesis and promotes adipogenesis in $\mathrm{C} 3 \mathrm{H}$ I0T(1/2) mesenchymal multipotent cells. Endocrinology 2005, I 46(8):3547-3557.

Publish with Bio Med Central and every scientist can read your work free of charge

"BioMed Central will be the most significant development for disseminating the results of biomedical research in our lifetime. "

Sir Paul Nurse, Cancer Research UK

Your research papers will be:

- available free of charge to the entire biomedical community

- peer reviewed and published immediately upon acceptance

- cited in PubMed and archived on PubMed Central

- yours - you keep the copyright

Submit your manuscript here:

http://www.biomedcentral.com/info/publishing_adv.asp
BioMedcentral 